\title{
THE CONTRIBUTION OF MUHAMMAD MAHFUZH AL- TARMASI TO THE HADITH STUDIES IN INDONESIA
}

\author{
Ali Masrur, Wawan Hernawan, Cucu Setiawan, Ayi rahman \\ UIN Sunan Gunung Djati Bandung \\ Jalan AH Nasution No. 105 Bandung, Jawa Barat Indonesia \\ E-mail: alimasrur@yahoo.com
}

\begin{abstract}
This study examines the contribution of Mahfuzh Al-Tarmasi, Javanese-born scholars, who live in Mecca in Hadith studies in Indonesia. This study employs a qualitative method with a historical approach to trace al-Tarmasi contribution in Hadith studies in Indonesia. After analyzing the primary and secondary sources, this study shows that Mahfuzh Al-Tarmasi is one of the prominent Islamic scholars of Indonesia in the nineteenth century who have contributed greatly and significantly to the study of hadith and the science of Hadith ('ilm al-riwayat) in Indonesia. The contribution of Mahfuzh Al-Tarmasi can be seen by the fact that he had so many students who learned Hadith and the science of Hadith from him, not only from Indonesia but also from abroad such as Malaysia, India and other countries. He also produced works in the field of Hadith and the science of Hadith. Besides that, he had explained the book Alfiyyah Al-Suyūțì by the title Manhaj Dhawì al-Nazhar: Sharh Manzhümah 'Ilm al-Äthār, a work containing science of Hadith, written only in four months. In this book, he had encreased twenty stanza poems to the book of Alfiyyah Al-Suyūtīi.
\end{abstract}

\section{Keywords:}

Mahfuzh Al-Tarmasi; Islamic boarding school Tremas; contribution; hadith studies; Indonesian Muslim scholar; Mecca

\begin{abstract}
Abstrak
Tulisan ini mengkaji kontribusi Mahfuzh Al-Tarmasi dalam kajian hadis di Indonesia. Setelah menelusuri berbagai sumber mengenai karya-karya Mahfuzh Al-Tarmasi, sejarah pondok pesantren Tremas, dan kontribusinya dalam kajian hadis, dengan menggunakan pendekatan historis, penulis menyimpulkan bahwa Mahfuzh Al-Tarmasi adalah seorang ulama besar di abad XIX M. yang telah memberi sumbangan yang sangat besar dan berarti bagi kajian hadis dan ilmu hadis ('ilm al-riwāyah) di Indonesia. Kontribusi Mahfuzh Al-Tarmasi ini dapat dibuktikan dengan adanya fakta bahwa ia memiliki banyak murid yang belajar kepadanya, tidak hanya dari Indonesia, tetapi juga dari manca negara, seperti Malaysia, India, dan lainnya. Beliau juga menghasilkan karya-karya di bidang hadis dan ilmu hadis. Lebih dari itu, ia telah mensyarah kitab Alfiyyah Al-Suyūțī dengan nama Manhaj Dhawī al-Naẓar: Sharḥ Manzūmah 'Ilm al-Āthār sebuah kitab yang berisi ilmu hadis, yang ditulis dalam empat bulan saja. Di dalam kitab ini, ia telah menambahkan 20 bait syair terhadap kitab Alfiyyah Al-Suyūṭ̂̄.
\end{abstract}

\section{Kata Kunci:}

Mahfuzh Al-Tarmasi; Pondok Pesantren Tremas; Kontribusi; Kajian Hadis Nusantara; Hadis dan Ilmu Hadis; Ulama Hadis Indonesia; Mekah..

DOI: $10.15575 / \mathrm{jw} . v 4 \mathrm{i} 1.1593$

Received: September 11, 2017; Accepted: December 19, 2018; Published: July 30, 2019. 
Ali Masrur, Wawan Hernawan, Cucu Setiawan, Ayi Rahman
The Contribution of Muhammad Mahfuzh Al-Tarmasi to the Hadith Studies in Indonesia

\section{A. INTRODUCTION}

In the history of Islam in Java at the end of the 19th century, a new spirit emerged in religious life. As a result of the increase in the number of Indonesian pilgrims to Mecca, religious teachers, and Pesantrens' students, there was also growing awareness that Islam has contributed to the growth of Indonesian proto-nationalism. The socio-economic, cultural, and political situation in Java as a result of Dutch politics grew awareness of the Islamic revival.

Furthermore, the development of sea relations between Europe and Asia, and of course with Java, especially by the opening of the Suez Canal in 1869, launched the process of spreading Islamic religion to rural areas on Java. In the last few decades in the 19th century, Java was beset by the intensity of Islamic life. The number of Islamic people who prayed five times a day went on pilgrimage and took part in education multiplies. Similarly, the number of Islamic Sufism organizations, religious books and leaflets containing Friday sermons also increased. ${ }^{1}$

Since the middle of the 19th century, many young Muslim Javanese people have been living in Mecca and Medina for several years studying religious teachings. Most of them became famous religious scholars and thus they taught in Mecca or Medina. Moreover, because of the involvement of these Javanese scholars in the realm of Islamic intellectualism and spiritualism centered in Mecca, they also influenced changes in the character of Islam in Java. The stronger their involvement in the Middle East's intellectual and spiritual life, the lesser their local character of Islam they practiced. Thus, they are influenced by the character of Islam in the Middle East.

${ }^{1}$ Zamakhsyari Dhofier, Tradisi Pesantren: Studi Tentang Pandangan Hidup Kyai, VI (Jakarta: LP3ES, 1994), 36-37.

${ }^{2}$ Dhofier, Tradisi Pesantren: Studi Tentang Pandangan Hidup Kyai, 36-37.
At the end of the 19th century, several Muslim Javanese clerics were recognized for their expertise in the Middle East. They became permanent teachers at the Great Mosque of Mecca, such as Muhammad Nawawi Banten and Muhammad Mahfuzh Tremas. Students from various regions in Java studying in Mecca were considered perfect in their studies after receiving the guidance from these Javaneseborn scholars. ${ }^{2}$

Mahfuzh al-Tarmasi, known as a prominent Javanese Muslim scholar, a Pesantren Tremas alumnus in Pacitan who wrote many important books and taught at the Great Mosque of Mecca in the latter half of the 19th century, was born in Tremas Village in 1285 H./1842 AD by the name of Muhammad Mahfuzh. ${ }^{3}$ His full name is Abu Muhammad, Muhammad Mahfuzh alTarmisi bin Demang Dipomenggolo I. He is later known in the Islamic world by the name "Sheikh Mahfuzh al-Tarmasi al-Jawi." His great grandfather, Dipemenggolo $\mathrm{I}$, is a descendant of a Surakarta Palace retainer named Ketok Jenggot. ${ }^{4}$

This research examines the contribution of Muhammad Mahfuzh al-Tarmasi in the study of Hadith in Indonesia. In particular, this research tries to seek the contribution of Mahfuzh al-Tarmasi in the study of Hadith and the science of Hadith as well as the contribution of Mahfuzh al-Tarmasi to Hadith scholars and the Pesantren's scholars in Indonesia.

This study contributes to the development of Hadith studies in the archipelago in particular; to Introduce an important and pioneering figure in the network of Indonesian Hadith scholars and to show evidence that the scholars of the Hadith of the archipelago are no less important than the scholars of Hadith in the Middle East.

\footnotetext{
${ }^{3}$ Muhammad Muhajirin, Mahfudz Al-Tarmasi: Ulama HadisNusantara Pertama (Yogyakarta: Idea Press, 2016), 27.

${ }^{4}$ Ahmad Fauzan, "Syekh Mahfudz Al-Tarmasi: Muhaddis Nusantara," Jurnal TAHDIS 9, no. 2 (2019): 119--145.
} 
Ali Masrur, Wawan Hernawan, Cucu Setiawan, Ayi Rahman
Contribution of Muhammad Mahfuzh Al-Tarmasi to the Hadith Studies in Indonesia
This is library research with the main sources of manuscripts, books, and some related literature. This study also used qualitative research that aims to obtain data on the biography of Shaykh Mahfuzh, starting from his journey of life, education and works, thus this research ultimately found out his contribution to the network of 20th century Islamic Hadith scholars.

Furthermore, this research used a descriptive-analysis method with a historical approach. This method aimed to reconstruct systematically and objectively the related previous studies through gathering, evaluating, verifying, and synthesizing evidence to establish facts and reach conclusions that can be accounted for.

As a well-known figure and has a very big role in the network of Nusantara Hadith Muslim scholars, this study found several similar studies that have traced the works of Mahfuzh al-Tarmasi as follows:

Sabri Mohamad stated that Mahfuzh alTarmasi was a famous figure of the Qirā'at, who was very active in writing in the field of Qirā'at as well as other sciences. ${ }^{5}$ Abdul Rahim bin Ahmad and Hayati bint Hussin stated that Mahfuzh al-Tarmasi was a prolific figure of Islamic studies and fiqh who had the opportunity to study and teach at Mecca. ${ }^{6}$

Fatkhul Mukhlies reported about alTarmasi's contribution in hadith studies by adding 20 additional stanzas, as a complement to the number of 1,000 Nazham Alfiyah al-

${ }^{5}$ Sabri Mohamad, "Syeikh Mahfuz Al-Tarmasi: Tokoh Ilmu Qira'at Nusantara," in Prosiding Nadwah Ulama Nusantara (Nun) IV, 2011.

${ }^{6}$ Hayati Hussin et al., "Contributions of Muhammad Mahfuz Al-Tarmasiy in The Field of Islamic Studies," International Journal of Engineering \& Technology 7,

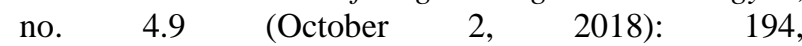
https://doi.org/10.14419/ijet.v7i4.9.20672.

${ }^{7}$ Fatkhul Mukhlies, "Peranan Syaikh Mahfuzh AlTarmasi Dalam Perkembangan Ulum Al-Hadits: Studi Kitab Manhaj Dzawi Al-Nazhar" (UIN Sunan Ampel, 2010).

${ }^{8}$ Abdurrahman Mas'ud, Dari Haramain Ke Nusantara: Jejak Intelektual Arsitek Pesantren (Jakarta:
Suyuti. ${ }^{7}$ Finally, Abdurrahman Mas’ud examines Mahfuzh al-Tarmasi contribution in the field of Islamic science particularly Hadith and called him an 'Allamah, al-Muhaddith, alMusnid, and even sometimes he was called alBukhari of the 19th century. ${ }^{8}$

\section{B. RESULTS AND DISCUSSION \\ 1. The History of Pesantren Tremas}

Tremas Islamic Boarding School is one of the oldest pesantren not only in East Java but also in Indonesia. ${ }^{9}$ Geographically, it is located in Tremas Village, Arjosari District, Pacitan Regency. The village of Tremas is located 11 kilometers from the city of Pacitan to the north and 1 kilometer from the Arjosari sub-district. The village of Tremas is surrounded by small circular hills where the north and east of the Tremas village flows the Grindulu river which always causes mud floods during the rainy season. Therefore, the foundations of villagers' houses are on average very high compared to the foundations of the houses in flood-free areas. $^{10}$

The residents' livelihoods are farming of several types of vegetables and fruits, such as rice, peanuts, coconuts, bananas, and so on. Because Pacitan located in a dry area, the Pacitan residents are lagging, especially in the economic field, compared to people in other regions. ${ }^{11}$

The pesantren named Tremas is derived from the words "Trem" and the word "Mas." "Trem" comes from the word "Patrem" which

Kencana, 2006). See also Abdurrahman Mas'ud, "Mahfūz Al-Tirmisī (D. 1338/1919): An Intellectual Biography," Studia Islamika 5, no. 2 (2014): 27-48, https://doi.org/10.15408/sdi.v5i2.752.

${ }^{9}$ Martin van Bruinessen, Kitab Kuning, Pesantren Dan Tarekat: Tradisi-Tradisi Islam Di Indonesia (Bandung: Mizan, 1999).

${ }^{10}$ Joko Sayono, "Perkembangan Pesantren Di Jawa Timur (1900-1942)," Jurnal Bahasa Dan Seni 33, no. 1 (2005): 54-69.

${ }^{11}$ Dimyathi, Mengenal Pondok Tremas Dan Perkembangannya, 22-23. 
Ali Masrur, Wawan Hernawan, Cucu Setiawan, Ayi Rahman
The Contribution of Muhammad Mahfuzh Al-Tarmasi to the Hadith Studies in Indonesia means a weapon or a small dagger (keris). While the word "Mas" means gold, a precious metal that is usually used as jewelry. It is reported that the name Tremas first established by Ketok jenggot who cleared the forest to establish the village and he put Golden Patrem weapon (Keris emas) in the place where he first cleared the forest. ${ }^{12}$

The establishment of Islam in Pacitan and in Tremas, in particular, started when Demak won the battle from the ruler of Pacitan Ki Ageng Buwana Keling who refused to embrace Islam. Three years later, a son from Demang Semanten named "Bagus Darso" returned from his study of Islamic teachings at the Pesantren Tegalsari Ponorogo under the guidance of Kyai Hasan Besari. Bagus Darso then established a Pesantren in Semanten village ( $2 \mathrm{KM}$ from north of Pacitan city) under the guidance of his father, R. Ngabehi Dipomenggolo. After that, he moved to Tremas and established a Pesantren Tremas. ${ }^{13}$

Since childhood, KH. Abdul Manan has been known to be intelligent and very interested in religious matters. He quickly mastered and understood the teachings of Islam beyond his friends until many stories emerged about his strengths. Darso's got married to Princess Demang Tremas R. Ngabehi Hongggowijoyo. ${ }^{14}$

The Pesantren was founded in 1830 AD when the Diponegoro war began to recede, and Kyai 'Abd al-Manan was the first teacher.

Pesantren Tremas is led by several prominent religious leaders consecutively as follows :

KH. Abdul Manan (1830-1862), KH. Abdullah (1862-1894), KH. Dimyati (18941934), K. Hamid Dimyati (1934-1948), KH. Habib Dimyati, KH. Haris Dimyati, KH.
Hasyim Ikhsan, and KH. Fuad Habib (1998 present).

\section{Mahfuzh al-Tarmasi: Biography, Educational History, and Works}

Mahfuzh al-Tarmasi, known as a prominent Javanese scholar, was an alumnus of the Pesantren Tremas, Pacitan. He authored many important books and taught at the Masjid alHaram Mecca in the latter half of the 19th century. He was born in Tremas Village in 1285 H. / 1842 AD under the name Muhammad Mahfuzh; while his full name is Abu Muhammad, Muhammad Mahfuzh al-Tarmasi bin Abdullah bin Abdul Manan bin Demang Dipomenggolo I al-Tarmasi al-Jawi. ${ }^{15}$ Later, he was known by the name "Sheikh Mahfuzh alTarmasi al-Jawi." His grandfather's father, Dipemenggolo I, was the descendant of a Surakarta Palace retainer named Ketok Jenggot.

Mahfuzh al-Tarmasi is a descendant of aristocratic scholars. Demang Dipomenggolo I is a respected aristocrat in Pacitan who is very religious. When Mas Tumenggung Jayakarya I came to power in Pacitan, a regent who was fond of broadcasting Islam, in Semanten Village, Ki Demang Dipemonggolo I established a Pesantren under his guidance. Demang Dipomenggolo eventually became quite famous and respected by all levels of Pacitan society. To give an example to his followers, he started from his own family. He sent his son, Mas Bagus Sudarso, to study religious knowledge at the Pesantren Tegalsari Ponogoro, a famous Pesantren at that time.

After returning from the Pesantren Tegalsari, Mas Bagus Sudarso was known by the name of Kyai 'Abd al-Manan. This young Kyai is actively developing the Pesantren Semanten, Pacitan. At that time, the village of

\footnotetext{
${ }^{12}$ Dimyathi, Mengenal Pondok Tremas Dan Perkembangannya, 22-23.

${ }^{13}$ Dimyathi, Mengenal Pondok Tremas Dan Perkembangannya, 22-23.
} 
Ali Masrur, Wawan Hernawan, Cucu Setiawan, Ayi Rahman
Contribution of Muhammad Mahfuzh Al-Tarmasi to the Hadith Studies in Indonesia
Tremas was ruled by Demang Ngabei Honggowijoyo who had a close relationship with Demang Dipomenggolo. both are descendants of Ketok Jenggot. Demang Ngabei Honggowijoyo was interested in the Young Kyai 'Abd al-Manan, son of Demang Dipomenggolo. He then married his daughter to 'Abd al-Manan and founded a new Pesantren in Termas.

From the marriage of Kyai 'Abd al-Manan to Princess Demang Ngabei Honggowijoyo, Abd Allah was born. To prepare qualified cadres, Abd Allah was sent to study at various Pesantrens in East Java and to the Land of the Hejaz. Finally, when Kyai 'Abd al-Manan died in 1962, Kyai' Abd Allah ibn 'Abd al-Manan replaced him as a teacher at the Pesantren Tremas. ${ }^{16}$

Mahfuzh al-Tarmasi learned to read the Qur'an and basic Islamic religious knowledge from the scholars in the land of Java. Before the age of Baligh (adult), he was able to memorize the Qur'an. When he was six years old, in 1291 $\mathrm{H} / 1874 \mathrm{AD}$, he was brought by his father to Mecca. While in Mecca, Mahfuzh al-Tarmasi began to be introduced to the main books in the field of Islamic studies: Aqeedah, interpretation, Hadith, Fiqh, Sufism as well as linguistics and literature. He considers his father, KH. Abdullah bin KH. Abdul Manan, as a father as well as a teacher. He often referred to his father as murabbī wa rūhī (my educator and my soul). ${ }^{17}$

Mahfuzh al-Tarmasi was born when the Pesantren was twelve years old. Since childhood, he lived in a Pesantren family who loves knowledge and are diligent in worship. He had studied religion with his grandfather. However, he studied deeply with his father, Kyai 'Abd Allah ibn' Abd al-Manan. He

\footnotetext{
${ }^{16} \mathrm{HS}$ Mastuki and M. Ishom El-Saha, Intelektualisme Pesantren: Potret Tokoh Dan Cakrawala Pemikiran Di Era Perkembangan Pesantren, 2nd ed. (Jakarta: Diva Pustaka, 2004), 103-104.

${ }^{17}$ Fauzi Deraman and Faisal Ahmad Shah, Pengajian Hadith Di Nusantara: Indonesia- Selatan ThailandSingapura (Kuala Lumpur: Jabatan Al-Quran dan Al-
}

studied Tawheed, al-Qur'an and al-Qur'an, and Fiqh to his father. In his father's teaching, he got pretty heavy learning with the Sorogan system (reading a text) from kitab kuning (originally means yellow book). ${ }^{18}$

In the 1870s, when Mahfuzh al-Tarmasi was a teenager, his father KH. Abdullah took him back to the land of Java and drove him to a famous Javanese cleric in the 19th century, KH. Shaleh Darat As-Samarani (1820-1903 AD) to study at his Pesantren in Semarang, Central Java.

Then, when Kyai 'Abd Allah ibn' Abd alManan held the Tremas Islamic Boarding School, his development was accelerating. Prospective students came from various parts of Java. The charism of the Kyai 'Abd Allah who had studied in the Holy Land of Mecca began to shine. Tremas Islamic Boarding School began to be known by the study of Arabic Grammar. Seeing this development, Kyai 'Abd Allah felt the need to prepare a successor better than himself. Finally, he decided to send his two sons Muhammad Mahfuzh and his younger brother, Dimyati, to Mecca to study their religion. This happened in 1872 AD when Mahfuzh al-Tarmasi was 30 years old. ${ }^{19}$

The wish of Kiai 'Abd Allah was welcomed by Mahfuzh al-Tarmasi. Because he did aspire to be always close to the Apostle of Allah and even to die in Mecca or Medina. Once he stepped on the Land of Haramain, he immediately intended to stay there until the end of his life. Together with his younger brother (Dimyati), he studied with prominent scholars in Mecca and Medina. When in Mecca, his father, KH. Abdullah bin Abdul Manan died in 1314 H./1896 AD and was buried in Ma'la. ${ }^{20}$

Hadith, Akademi Pengajian Islam Universiti Malaya, n.d.), 49-50.

${ }^{18}$ Mastuki and El-Saha, Intelektualisme Pesantren: Potret Tokoh Dan Cakrawala Pemikiran Di Era Perkembangan Pesantren, 104-105.

${ }^{19}$ Mastuki and El-Saha, Intelektualisme Pesantren.

${ }^{20}$ Mastuki and El-Saha, Intelektualisme Pesantren. 
Ali Masrur, Wawan Hernawan, Cucu Setiawan, Ayi Rahman
The Contribution of Muhammad Mahfuzh Al-Tarmasi to the Hadith Studies in Indonesia
After living and teaching at the al-Haram Mosque in Mecca for about 42 years, in 1338 H./1920 M. Mahfuzh al-Tarmasi died leaving a priceless scientific heritage. His desire to die and be buried in Mecca or Medina came true. He was buried in Ma'la Mecca near the tomb of Ummul Mukminin Sayyidah Khadijah, wife of the Prophet Muhammad. ${ }^{21}$

The spirit of Mahfuzh al-Tarmasi to study Islamic sciences is very high. This is evidenced by the number of teachers he met until he wrote a complete work on the names of his very important teachers in Kifāyatul Mustafìd Li Mā 'Alā min al-Asānīd. ${ }^{22}$

Al-Tarmasi is also known as a very productive scholar in writing. He had a lot of papers in various fields of science: Islamic Jurisprudence, Hadith studies, Hadith Mustith, Qiraat and others.

Mahfuzh al-Tarmasi's works reach eighteen books, namely: ${ }^{23}$ al-Badru al-Munīr fi Qirā’ati al-Imam Ibn Kathīr (makhțūt / manuscript), alFawā'id al-Tarmasiyah fi Asānīd al-Qirā'at al'Ash'ariyyah (mațbū '/ already printed), Ganiyyah al-Abahalabah bi Sharhi Naẓam alȚayyibah fì al-Qirā'ah al-Așriyyah (muhaqaqaq), Inshiraḥ al-Fu'ād fī Qirā'ati alImām Hamzah (makhțūt), Ta'mīm al-Manāfi 'fị Qirā ati al-Imām Nāfi' (makhțūt), Tanwīr alȘudūr fī Qirā’ati al-Imām Abi 'Amr (makhṭūt), Fath al-Khabīr bi Sharh Miftah al-Tafsīr (makhțūt), al-Khil'ah al-Fikriyyah Sharh alMinhah al-Khairiyyah, (mațbū '), al-Minhahah alKhairiyah fi Arba'īna Hadīthan min Ahādīth Khair al-Bariyyah (mațbū '), Manhaj Dhawī alNaẓar fī Sharh Manẓūmah 'Ilmi al-Āthār (mațbū'), al-Siqāyah al-Marḍiyyah fi Asmā’i al-Kutubi al-Fiqhiyyah al-Shāfi'iyyah (mațbū '), Mawhibah Dhī al-Faḍl Hashiyah 'Alā Sharh Mukhtașar Bafạ̣al (Hashiyah al-Tarmasī) (mațbū'), Is'āf al-Mațali 'bi Sharh al-Badr alLāmi’ Naẓam Jam'i al-Jawāmi '(muḥaqqaq),
Nayl al-Ma'mūl bi Hashiyah Ghāyah al-Wușūl Fī 'Ilmi al-Ușul (makhțūt), Tahayyu` al-Fikr bi Sharh Alfiyyah al-Sayr (makhțūț), ā Ināyah alMuftaqir F̄i mā Yata'allaqu bi Sayyidina alKhiḍr (maṭbū '), Bughyah al-Adhkiyā 'fī Baḥth' an Karāmah al-Auliyā ', Kifāyah alMustafìd Limā 'Alā min al-Masānīd (maṭbū'). Hāshiyah Takmilah al-Manhaj al-Qawīm ilā alFarā'id 1 volume, Thulāthiyyāt al-Bukhārī 1 part.

al-Tarmasi's work that received the most attention and became a reference for the scholars afterward was the Hasyiyah alTarmasi book; a book of Syafi'i school of Fiqh. That work is al-Tarmasi's greatest work in the field of Fiqh. Hashiyah al-Tarmasī was written complete with analysis, tahqīq, and accuracy. He can reveal the hidden and explain it very clearly. This book can collect the opinions of the scholars and arrange them neatly. Hashiyah al-Tarmasī was completed in Mecca and was printed and published by Dar al-Minhaj in Riyadh, Saudi Arabia in 2011 AD, with a total of seven volumes. ${ }^{24}$

Another important work that explains the depth and discipline of al-Tarmasi science is the book of Kifayyah al-Mustafid. This book contains the scientific chronicles of al-Tarmasi which he received from the Haramayn scholars, Mecca-Medina, in various fields of science such as interpretation, Hadith studies, Islamic jurisprudence, language, Ushul, Tasawwuf (Islamic mysticism) and Wirid. The book was written as a form of al-Tarmasi's attention to the importance of the knowledge of Sanad and its importance, which according to him, was not appropriate for a pious person to study science without Sanad. Imam Shafi'i said, "people who study knowledge (Hadith) without Sanad, such as people who search for

\footnotetext{
${ }^{23}$ Muhajirin, Mahfudz Al-Tarmasi: Ulama HadisNusantara Pertama.

${ }^{24}$ Mas'ud, Dari Haramain Ke Nusantara: Jejak Intelektual Arsitek Pesantren.
} 
Ali Masrur, Wawan Hernawan, Cucu Setiawan, Ayi Rahman
Contribution of Muhammad Mahfuzh Al-Tarmasi to the Hadith Studies in Indonesia firewood at night and bring it even though there is a snake inside, but he does not know it." ${ }^{25}$

Kifāyah al-Mustafīd has been printed by two publishers namely al-Fikrah publisher in Yogyakarta and Dar al-Basyair al-Islamiyyah publisher in Beirut, Lebanon. This book was written by al-Tarmasi on 19 Safar 1320 H / 28 May 1902 AD in Mecca. ${ }^{26}$

Besides Kifāyah, in the field of Hadith, alTarmasi wrote al-Khil'ah al-Fikriyah Bi Sharh al-Min -ah al-Khayriyyah fì Arba'ìn Hadìthan min Ahādìthi Khayri al-Bariyyah. The book contains forty prophetic Hadiths. al-Khil'ah alFikriyah is an explanation (Sharh) of the book al-Minhah al-Khayriyyah which contains 40 traditions of Thulathiyyāt namely the Hadith between the narrators and the Prophet there are three people; friends, Tabiin and followers of Tabiin (Tâbi 'al-Tābi'īn). The strength of this book is that each Hadith is mentioned complete with its Sanad and the biography of the Hadith scholars who narrate it. The book al-Minhah alKhayriyyah was completed on Monday 16 Ramadhan 1313 H / March 1, 1896 AD While the book of Shariah al-Khil'ah al-Fikriyah was completed on Tuesday 8 Dhul Qa'idah on the same year / 21 April 1896 AD. This means that al-Tarmasi wrote his Sharah in only a span of 1 month and 21 days. ${ }^{27}$

In addition, he also wrote a Musthalah book of Hadith entitled Manhaj Dhawi al-Nazar, which is an annotation book (Sharh) on Nazam Alfiyyah al-Suyūṭi which contains about the science of Hadith; includes discussions on the distribution of Hadith such as sahīh, hasan, da'îf, Musnad, Marfū', Mursal, Mu'allaq, Mu'an'an, Tadlīs, Munkar, Ma'rūf, Matrūk, Ifrād, Gharīb,' Azīz, Mashūr, Mustafīẹ, Mutawātir, Mawḍ̄̄'. Besides, the history of the writing of the Hadith, etiquette for the Hadith experts, Hadith seekers of manners, Nasikh
Mansukh, understanding shahabah, Tabiin and discussion of the differences in siqat and dẹa'if in the Hadith.

al-Tarmasi's annotation of the book Nazam Alfiyyah al-Suyūți is recognized by many as the best in understanding al-Suyūṭ̂’'s thoughts. AlTarmasi wrote Manhaj Dhaw̄ al-Nazar in Mecca at the beginning of Dhu al-Hijjah in $1328 \mathrm{AH}$ and was completed on Friday the 14th of the Final Rabi'l in 1329 H. In other words, the book was written in only four months and fourteen days. Remarkably, this book has been printed by three publishers in three countries namely the al-Haramain publisher, Surabaya, Indonesia; the Dar al-Fikr Egyptian publisher, and third the Dar al-polar publisher al-Ilmiyah Beirut, Lebanon. ${ }^{28}$

Another one of al-Tarmasi's work which proves his foresight and sharpness of analysis is the book of Bughyah al-Adhkiya 'fi Bahthi' an Karāmah al-Awliyā', a book of Sufism that discusses the supernatural powers of saints. The discussion was taken by al-Tarmasi from two main books: the book of al-Ṭabaqāh alKubrā, the work of al-Taj al-Subki and the work of al-Muhaqqiq Ibn Hajar al-Haitami. Both books are considered as the most complex books related to Karamah because it is accompanied by strong argumentations who can answer various doubts about Karamah. This book was finished written by Mahfuzh alTarmasi just before Maghrib on Sunday 18 Rabiul Awal 1337 H. $^{29}$

\section{a. Teachers of al-Tarmasi}

According to Abdurrahman Mas'ud, alTarmasi's way of getting knowledge varies. Generally, he often reads books in front of his teachers, waiting for corrections and comments from his teachers. Besides, he sometimes focused his attention on what was described in

\footnotetext{
${ }^{25}$ Muhammad Mahfuzh Al-Tarmasi, Kifāyatul Mustafìd Li Mā 'Alā Min Al-Asān̄̄d, ed. Muhammad Yasin bin 'Isa Al-Fadani Al-Makki (Mekkah AlMukarramah, n.d.).

${ }^{26}$ Dzul Kifli Hadi Imawan, Al-Tarmasi: Ulama Tanah Suci Dari Tanah Jawi, 2015.
} 
Ali Masrur, Wawan Hernawan, Cucu Setiawan, Ayi Rahman
The Contribution of Muhammad Mahfuzh Al-Tarmasi to the Hadith Studies in Indonesia the assemblies in the mosques. In the first or second case, he is a dynamic student. His passion for enriching himself with Islamic science can be seen from various teachers he met. In Kifāyatul Mustafĩd, Mahfuzh alTarmasi left a complete list of his teachers in all fields of science he had worked on. ${ }^{30} \mathrm{Al}$ Tarmasi's teachers are K.H. Abd. Allah (d. 1314 H / 1896 AD), his father, K.H. Saleh Darat, namely Muhammad Shaleh bin 'Umar as-Samarani (Semarang, 1903 AD), ${ }^{31}$ Sayyid Abu Bakr ibn Muhammad Zain al-Abidin Shata al-Makki. Born in Mecca in 1226 AH and died in $1310 \mathrm{H}$. Sheikh Ahmad al-Munshawi, known as Muqri',Shaykh 'Umar bin Barakat alShami al-Biqa'i al-Azhari al-Makki al-Shafi'i, Sheikh Mustafa bin Muhammad ibn Sulayman al-'Afifi, al-Habib Husayn bin Muhammad ibn Husayn al-Habsyi al-Shafi'i, Sheikh Muhammad Sa'id bin Muhammad Babasil alHadrami al-Shafi'i al-Makki, Sayyid Ahmad al-Zawawi al-Makki, Sheikh Muhammad alSyarbani al-Dimyati, Sayyid Muhammad Amin bin Ahmad Ridhwan al-Madani. ${ }^{32}$

Wan Saghir argues that some Meccan scholars are not mentioned by al-Tarmasi as his teacher. In fact, there are among those who are close friends of his teacher, such as Sheikh Ahmad al-Fatani who was asked by Shaikh alShatta to examine one of his works. Among the teachers not mentioned are Muhammad bin Sulayman Hasbullah al-Makki, Nawawi alBantani and Ahmad al-Fathani. ${ }^{33}$

\section{b. Students of al-Tarmasi}

He had many competent and smart students, not only from the Nusantara students but from several continents including Arab students at that time. The following is a list of students of

\footnotetext{
${ }^{30}$ Al-Tarmasi, Kifāyatul Mustafìd Li Mā 'Alā Min AlAsānìd, 7-8.

${ }^{31}$ Mas'ud, Dari Haramain Ke Nusantara: Jejak Intelektual Arsitek Pesantren, 169.

${ }^{32}$ Hussin, "Al-Tarmasi Dan Sumbangannya Dalam Fiqh Mazhab Shafi'i”, 7

${ }^{33}$ Hussin, "Al-Tarmasi Dan Sumbangannya Dalam Fiqh Mazhab Shafi'i”, 8.
}

al-Tarmasi: ${ }^{34}$ Ali bin Mahmud bin Muhammad Arsyad bin Abdullah al-Banjari, Muhammad Dimyati at-Tarmasi, his brother, Umar bin Abi Bakr bin Abdullah bin Umar bin Ali bin Muhammad al-Bajind al-Hadrami al-Makki,

Muhammad Habib bin Abdullah bin Ahmad al-Shanqiti,

Muhammad Hasyim Asy'ari,

Muhammad Baqir al-Jawi al-Mariki,

Baqir bin Muhammad bin Nur bin Fadhil Ibrahim al-Jokjawi, Umar bin Hamdan bin Umar al-Mahrasi al-Madani al-Makki, Maksum bin Ahmad bin Abdul Karim alLasemi al-Shafi'i,

Abdul Wahab bin Hasbullah al-Jumbani,

Mahfuzh al-Tarmasi was married to a woman from Demak, Central Java, who came to Mecca to perform the pilgrimage. From this marriage, Mahfuzh al-Tarmasi was blessed with three children namely 'Aishah, Fatimah, and Muhammad, but only Muhammad lived, while his two sisters died when they were under the age of five.

As a child, Muhammad had received strong support from Shaykh Mahfuz for learning and memorizing the Qur'an. This will be fulfilled until he succeeded in becoming a pious person in the field of recitation of the Koran and also succeeded in growing Pesantren, namely Bustan 'Ushshaq al-Qur'an in Demak, Kudus, Central Java, which now has many students from all over the archipelago. ${ }^{35}$

Mahfuzh al-Tarmasi died in Mecca, at the age of 52 at the beginning of the Rajab month before Maghrib on Sunday, Monday night 1338 H / March 1920 AD His body was accompanied by many people and is buried in Ma'la, Mecca al-Mukarramah. ${ }^{36}$

\footnotetext{
${ }^{34}$ MaHussin, “Al-Tarmasi Dan Sumbangannya Dalam Fiqh Mazhab Shafi'i”, 8s'ud.

${ }^{35}$ Deraman and Shah, Pengajian Hadith Di Nusantara: Indonesia-Selatan Thailand-Singapura, 51.

${ }^{36}$ Imawan, Al-Tarmasi: Ulama Tanah Suci Dari Tanah Jawi, 91-93.
} 
Ali Masrur, Wawan Hernawan, Cucu Setiawan, Ayi Rahman
Contribution of Muhammad Mahfuzh Al-Tarmasi to the Hadith Studies in Indonesia

\section{Contribution of Mahfuzh al-Tarmasi to the Hadith Studies in Indonesia}

In the latter half of the 19th century, there are several recognized Indonesian Muslim scholars who have the opportunity to teach their knowledge at the Masjid al-Haram. There are at least seven prominent ulama namely Shaykh Mahfuzh al-Tarmasi (East Java), Shaykh Nawawi al-Bantani (West Java), Shaykh Ahmad Khatib al-Minangkabawi (West Sumatra), Shaykh Mukhtarom Banyumas (Central Java), Shaykh Bakir Banyumas (Central Java), Shaykh Ash'ari Bawean (East Java), and Shaykh 'Abdul Hamid Kudus (Central Java).

Mahfuzh al-Tarmasi is one of the scholars who gain recognition from many Muslim scholars in Muslim world who gave a significant contribution to teaching and learning at Masjid al-Haram. The learning process at the Masjid al-Haram uses halaqah learning system, where students sit around a teacher or other knowledgeable person. This system is still maintained as the main method of teaching and learning process in the Masjid al-Haram. Halaqah is usually held in the morning after Fajr, 'Asr, Maghrib and Isha'. During the daytime, educational activities moved to madrassas around the Grand Mosque. ${ }^{37}$

Regarding learning at the Masjid al-Haram, Shaykh Mahfuzh in charge of Hadith and 'Ulūm al-Hadis, which is his specialty. During the halaqah, Shaykh Mahfuzh sat in a certain place in the Masjid al-Haram facing the Kaaba, while his students sat around him. There are several types of teaching and learning methods used by Shaykh Mahfuzh. First, the teacher reads the learning material then explains it. Second, the teacher reads the learning material, then the student continues. Third, students read the learning material in front of the teacher,

\footnotetext{
${ }^{37}$ Azra, Jaringan Ulama Timur Tengah Dan Kepulauan Nusantara Abad XVII Dan XVIII: Melacak Akar-Akar Pembaruan Pemikiran Islam Di Indonesia, 79-80.
}

then the teacher gives a correction to the student's reading. In all these three methods the teacher allow the students to ask questions.

A distinctive feature of Shaykh Mahfuzh alTarmasi in teaching at the Masjid al-Haram is his proficiency in using Arabic fluently which is often interspersed with Javanese. The use of Javanese is inseparable from the number of students of Shaykh Mahfuzh who came from Java; although many students of Shaykh Mahfuzh came from outside Java, even abroad such as Thailand, Malaysia, India, and Syria. ${ }^{38}$

Mahfuzh al-Tarmasi began teaching at the al-Haram Mosque since 1890. When his father died, on Monday evening Tuesday, 29 Sya'ban in $1314 \mathrm{H} / 1894 \mathrm{AD}$, he sent his younger brother, Dimyati, back to Java and he became a cleric in Tremas. While Shaykh Mahfuzh chose a career in Mecca, where he became an accomplished teacher.

In addition to being active as a teacher in the Masjid al-Haram, his role and scientific contribution, in particular, and in the field of $\overline{\mathrm{u}}$ Ulūm al-hadīth are to write several books in various scientific disciplines, including in 'Ulūm al-Hadīth. Mahfuzh al-Tarmasi is one of the productive Muslim intellectuals. His productivity is proof of his intellectual intelligence. Mahfuzh al-Tarmasi was also a multidisciplinary scholar who succeeded in writing. There are at least 10 fields of study: Fiqh, ușūl Fiqh, knowledge of Tawheed, Sufism, the life of the Prophet, a collection of Hadith, Muștalah al-1̄adīth, inheritance, knowledge of reading the Koran, and Morals.

Among Javanese Muslim clerics, Mahfuzh al-Tarmasi is known as an expert on Hadith. He is also recognized as a legitimate isnād (chain) in the intellectual transmission of teaching Șahịh Bukhārī. This certificate comes directly from Imam Bukhari himself, who was written about 1000 years ago and handed over in chains through 23 generations of scholars who have

\footnotetext{
${ }^{38}$ Mukhlies, "Peranan Syaikh Mahfuzh Al-Tarmasi Dalam Perkembangan Ulum Al-Hadits: Studi Kitab Manhaj Dzawi Al-Nazhar."
} 
Ali Masrur, Wawan Hernawan, Cucu Setiawan, Ayi Rahman
The Contribution of Muhammad Mahfuzh Al-Tarmasi to the Hadith Studies in Indonesia mastered ḥaḥ̄ị Bukhārī; Shaykh Mahfuzh was the last link at that time.

In the field of Hadith, Mahfuzh al-Tarmasi composed Thulāthiyyāt al-Bukhārī, Minhaha alKhayriyyah, and aI-Kil'ah al-Fikriyyah bi Sharh al-Minhah al-Khayriyyah. The most popular book among his works in the field of Hadith is the book of Minah al-Khayriyyah. This 51-page book contains 40 selected Hadith.

Regarding the collection of 40 Hadith, Mahfuzh al-Tarmasi is not the first person. Many scholars have previously made the same effort. Besides Shaykh Mahfuzh, some scholars collect 40 Hadiths in one book. The first scholar to do so was Abdullah bin al-Mubarak 118-181 $\mathrm{H} /$ 736-797 AD, then Imam al-Nawawi (631$676 \mathrm{H} /$ 1233-1277 AD), in his famous book, al-'Arba'inn al Nawawiyyah, Shaykh Yasin alPadani also collected 40 Hadiths using Shaykh Mahfuzh's Sanad from beginning to end, then Shaykh Ismail 'Usman al-Yamani in his book' Arba'īn Hadīthan min Kalami Khayr al-Anām fī al-Mawa` iḍi wa al-Nashā'ikhi wa al-Aḥkām, also al-"Alim al-Sayyid Salih ibn Ahmad Idrus in his book Fayḍ al-'lam fì 'Arba'īn Hadīthan fì al-Salām. The advantages of the collection of 40 Hadith Shaykh Mahfuzh are that in it 22 Hadiths are originating from Thulāthiyyāt alBukhārī. ${ }^{39}$

The Thulāthiyyat Hadith is a Hadith that has only three narrators in the sanad chain that started from the Prophet Muhammad. Therefore, the value of the hadith narrated is considered very high. If seen from the strength of his Sanad and Matan, the work of Shaykh Mahfuzh can be said to be the foremost among several similar works. Shaykh Mahfuzh received the Thulāthiyyāt from his teacher, Shaykh al-Sayyid Abu Bakr ibn al-Sayyid Muhammad Syatha: ${ }^{40}$

This book has been published by Islamic Boarding School Bustanul Usyaqil Quran,
Betengan, Demak, on the initiative of Shaykh Mahfuzh's grandson, namely K.H. Hariri bin Muhammad bin Shaykh Mahfuzh al-Tarmasi, and has circulated widely in several Pesantren in Java. In his introduction, K.H. Maimun Zubair, the head of the al-Anwar Islamic Boarding School, Sarang, Rembang, dubbed Shaykh Mahfuzh as Shaykh al-Mashaykh alA'lām wa Qudwatu al-Ānām or the great teacher of knowledgeable masters and role models. A proper nickname, because indeed from his hand were born dozens of great scholars and dozens of monumental works. ${ }^{41}$

As for the study of Hadith, Mahfuzh alTarmasi wrote the books of Manhaj Dhawī alNaẓar and Kifāyah al-Mustafīd li Ma 'alā Min al-Asānīd. The Manhaj Dhawī al-Naẓar is a Sharh (review) of the Man kitabūmah 'Ilm alĀthār by al-Suyuți (d. $911 \mathrm{H})$. Experts and lecturers at al-Azhar University, Cairo, consider it to be one of the best Sharhs in the Naẓam of Atharī studies. ${ }^{42}$

It is not difficult to understand why Mahfuz prefers the science of Hadith to other fields of science. According to him, experts from various disciplines considered that the scientific discipline was the best. The theologians will maintain that theology is the most excellent science because the oneness of God is established with the help of this science, while jurists state that the glory of Fiqh is not in doubt due to the fact that the practices of Fiqh, halal, haram, and everything related to Islamic law have been correctly confirmed. The commentators also view that the supremacy of the science of the Qur'an is in a central position, where all branches of science refer to it. Seeing the benefits of these sciences, Mahfuz concluded that 'ilm al-āthār or the science of Hadith is the science that is absolutely - the most important of all. This opinion is based on the fact that one can return

\footnotetext{
${ }^{39}$ Mukhlies, "Peranan Syaikh Mahfuzh Al-Tarmasi Dalam Perkembangan Ulum Al-Hadits."

${ }^{40}$ Mukhlies, "Peranan Syaikh Mahfuzh Al-Tarmasi Dalam Perkembangan Ulum Al-Hadits.”
} 
Ali Masrur, Wawan Hernawan, Cucu Setiawan, Ayi Rahman
Contribution of Muhammad Mahfuzh Al-Tarmasi to the Hadith Studies in Indonesia to the noblest creature, Muhammad SAW, through this knowledge by knowing the authenticity of his words and deeds. ${ }^{43}$

Mahfuzh al-Tarmasi shows that in reality, the purity of isnād science is very convincing for those who master science. This supremacy is never questioned by those who have religious understanding, intellect, and common sense. In his important book, he writes: "It is truly glorified by Allah those who are experts in the sciences of this person (unlike other people before Muhammad)." By quoting the Prophet's words, Mahfuzh considers that science is religion, and daily prayer is also religion, so one must pay attention to where the place of knowledge is obtained and how he observes his prayer. Everyone will be held accountable in the hereafter. Isnād is part of religion. As a result of shallowness in this substantial device, one will say whatever he wants (out of control without a religious basis). ${ }^{44}$

As a student of the Hadith, Mahfuzh alTarmasi realizes and reminds himself and others about the danger of delivering a false Hadith by referring to the Prophet's warning: Someone who says what I have never said (and considers it to be from me), be prepared to be the inhabitants of hell. "In that context, Mahfuz decided to engage in the science of Hadith and maintain it as the focus of his studies and also as the most excellent religious science. ${ }^{45}$

To convince his readers, Mahfuzh alTarmasi quoted several convincing paragraphs. Ash-Shafi'i considers that people who are looking for Hadith without isnād are like wood seekers at night who carry wood and neglect that there are poisonous snakes inside. Some Salaf scholars state that isnād is like a sword, if it fails to grasp it, how can he win the battle. Yahya bin Mu'in (d. $333 \mathrm{AH}$ ) confirmed that a substantially noble isnād would be able to bring someone closer to Allah and His Messenger.

\footnotetext{
${ }^{43}$ Mas'ud, Dari Haramain Ke Nusantara: Jejak Intelektual Arsitek Pesantren, 171.

${ }^{44}$ Mas'ud, Dari Haramain Ke Nusantara: Jejak Intelektual Arsitek Pesantren, 171.
}

Mahfuzh al-Tarmasi writes for the benefit of his religion. However, the clearest motivation in the effort to gather the Hadith arises from the expressions that are in the Hadith itself. "Those who maintain 40 Hadith for the sake of their religion, will be included in the group of jurists and scholars in the hereafter or they will enter [heaven] through whatever door they like." Because of this promise, some scholars who lived before and after Mahfuz were more inclined to carry out the same mission, namely gathering at least 40 Hadiths. For example, Abu Zakariya an-Nawawi ad-Dimasyqi (d. 675/1276), one of the most famous scholars who lived before (Mahfuzh), and Yasin alFadani, a muhaddithūn and the Musnid who lived afterward. ${ }^{46}$

It is noteworthy that Mahfuzh al-Tarmasi obtained many certificates in various fields from authors who lived before the 15th century. These fields consisted of the science of interpretation, Hadith, Jurisprudence, tools (Nahwu-Sarf), ușūl, and the science of Sufism and Aurad (aurad (aurad) wirid-wirid). Such certificates that have unbroken transmission links are placed in his work, Kifäyah alMustafid. What is interesting is that Mahfuz gained authenticity regarding the transmission of interpretations which originated from ArRazi (d. 606/1211 CE). Although Ar-Razi is an encyclopedic Sunni scholar who is perfectly knowledgeable, his interpretation book is not widely used by the Santri community. Thanks to his opposition to the enemies of the Sunnis, his position remains noble in the Pesantren tradition. Related to this, Mahfuz's belief that Razi's interpretation has given him more praise in the eyes of the Pesantren scholars. Ar-Razi is believed to be a reformer (Mujaddid) in the 6th century H / 12 AD or post-al-Ghazali. Like other Sunnis in the Islamic world, the Pesantren community fully believes in the Hadith and establishes its criteria for identifying reformers

\footnotetext{
${ }^{45}$ Mas'ud, Dari Haramain Ke Nusantara: Jejak Intelektual Arsitek Pesantren.

${ }^{46}$ Mas'ud, Dari Haramain Ke Nusantara: Jejak Intelektual Arsitek Pesantren.
} 
Ali Masrur, Wawan Hernawan, Cucu Setiawan, Ayi Rahman
The Contribution of Muhammad Mahfuzh Al-Tarmasi to the Hadith Studies in Indonesia in each century. Al-Ghazali, for example, is seen as the ideal reformer of the 5th century $\mathrm{H}$ / $6 \mathrm{AD}$. This is in line with the sound of a fairly popular Hadith, "Indeed, Allah will send to these people at the beginning of a century someone who will improve their religion." 47

In line with Mahfuzh al-Tarmasi's specialization, it is important here to revisit Mahfuzh's writings about his trusted teachers who refer to al-Bukhari as an illustration. Mahfuzh's authority is to teach and deliver alJami 'al-Ṣahịh, a collection of Hadith alBukhari, and also give ijāzah to students who are considered capable. Mahfuzh studied the entire contents of the Hadith collections in front of his main teacher, Abu Bakr bin Muhammad Syata al-Makki, waiting for his corrections and comments. Mahfuzh completed the same task, as he said, at least four times. Previously, Abu Bakr also did the same thing in front of his teacher. The list of scholars from his teacher Abu Bakr to al-Bukhari is as follows: Ahmad bin Zaini Dahlan, Sheikh Uthman bin Hasan ad-Dimyati, Sheikh Muhammad bin Ali asSyanwani, Isa bin Ahmad al-Barawi, Sheikh Muhammad ad-Dafri, Sheikh Salim bin Abd. Allah al-Basri, named after his father Abd. Allah bin Salim al-Basri, Sheikh Muhammad bin Ala ad-Din al-Babili, Sheikh Salim bin Muhammad as-Sanhuri, an-Najm Muhammad bin Ahmad al-Ghaiti, Sheikh al-Islam Zakariyya bin Muhammad al-Ansari al-Hafizh, Ahmad ibn Ali ibn Hajar al-Asqalani (d. $852 \mathrm{H}$ / 1448 AD), Ibrahim ibn Ahmad at-Tanuhi (d. 800/1397); Abu al-Abbas Ahmad bin Talib alHajar (d. 733/1332), al-Husain ibn al-Mubarik az-Zubaidi (somewhere in Yemen) al-Hanbali (d. 631/1233), Abu al-Waqt Abd al-Awwal bin Isa as-Sijzi (attributed to Sijistan), Abu alHasan Abd. ar-Rahman bin Muzaffar bin Dawud ad-Dawudi, Abu Muhammad Abd. Allah bin Ahmad as-Sarakhsi (somewhere in
Khurasan), Abu Abd. Allah Muhammad ibn Yusuf ibn Matar al-Faribari, a place near Bukhara (d. 320/932), al-Imam al-Hafizh Abu Abd Allah Muhammad ibn Isma'il bin Ibrahim al-Bukhari (d. 256/869). ${ }^{48}$

Mahfuzh al-Tarmasi also obtained another authority from the transmission of Hadith alBukhari from a different path which he believed was higher, but less hierarchical. They are as-Sayyid al-Husain ibn Muhammad alHabasha (d. 1281/1864), his father Muhammad ibn Husayn al-Habasha (d. 1230/1814), Shaykh 'Umar bin Abd. al-Karim al-Attar (d. 1249/1833), Sayyid Alibin Abd, al-Barr alWana'i (d. 1211/1796), Abd al-Qadir bin Ahmad bin Muhammad al-Andalusi, Muhammad bin Abd. Allah al-Idrisi, al-Qutb Muhammad bin Ala'uddin an-Nahrawi, somewhere in India (d. 988/1580), his father, Abu al-Futtuh Ahmad bin Abd. Allah atTawusi, Baba Yusuf al-Harwi, Muhammad bin Shad al-Farghani, 121 Abu Luqman Yahya bin Ammar al-Khuttalani (in Turkey), Muhammad bin Yusuf al-Faribari, from al-Imam alBukhari. $^{49}$

As a musnid and muhaddith, Mahfuzh obtained recognition for transferring the collection of Hadith not only from al-Bukhari but also from other givers. The scholars and their works are as follows: Sahị Muslim (d. 261H), Sunan Abu Dawud (d. 275), Sunan AtTirmidhi (d. 279), Sunan Nasa'i (d. 303), Sunan Ibnu Majah (d. 273), Muwatta 'Malik bin Anas (d. 179), Musnad Imam Shafi'i (d. 204), Musnad Imam Abu Hanifah (d. 150), Musnad Ahmad bin Hanbal (d. 241), Mukhtașar bin Abu Jumra (d. 695 AH in Egypt), Arba'inn Nawawiyyah an-Nawawi (d. $676 \mathrm{AH}$ ), and al-Jāmi al-Șaghīr by Ali ibn Ibrahim al-Halabi (d. 1044 H). ${ }^{50}$

\footnotetext{
${ }^{49}$ Al-Tarmasi, Kifāyatul Mustafìd Li Mā 'Alā Min AlAsānīd.

${ }^{50} \mathrm{Al}$-Tarmasi, Kifāyatul Mustafìd Li Mā 'Alā Min AlAsānīd.
} 
Ali Masrur, Wawan Hernawan, Cucu Setiawan, Ayi Rahman
Contribution of Muhammad Mahfuzh Al-Tarmasi to the Hadith Studies in Indonesia

\section{Contribution of Mahfuzh al-Tarmasi towards Hadith Scholars and the Pesantren Scholars in Indonesia}

Mahfuzh's association with his students and teachers is more significant when compared to other Muslim scholars who do not have the authorization to continue the diploma in the science of Hadith like Mahfuzh's had. The intensity of such Muslim religious affiliation is at some level no less crucial than the membership of the Tariqa. When Tariqa membership in Java was strengthened, mainly by the loyalty and struggle of students to improve the quality of their piety under the guidance of a Sufi teacher, Mahfuzh's affiliation with his students was intensified by the persistence of his students to improve their knowledge to obtain blessings and careers. Martin van Bruinessen concluded that Mahfuzh was the most famous figure among the Kyai today and one of the most educated Javanese scholars. This is because he is in a prestigious position, namely as a teacher who is highly respected by many Muslim scholars who founded NU. ${ }^{51}$

While concluding an introduction to one of Mahfuzh's Hadith collections, al-Minhaj alKhayriyyah, Kyai Maimun Zubair, an influential Pesantren leader in the 20th century in Serang, Central Java, convinced his readers in Arabic that the author of the book is alAllamah ash-Shaykh Mahfuzh at-Tarmasi, Shaykh al-Mashāyikh al-'Ālam (the most knowledgeable Master) and a prime example for the Pesantren community. $\mathrm{He}$ recommended that everyone at any educational institution in the archipelago take advantage of this book by hoping for blessings and reviving the Sunnah of the Prophet. ${ }^{52}$

Indeed, Mahfuzh al-Tarmasi is a very interesting teacher. Although there are no definite records of the number of students, it can be assumed that there are more than 4,000 students from various generations and nationalities. These statistics are based on the period of his teaching activities at Masjid alHaram, which ran effectively from the beginning of the 1890s to the end of the second decade of the 20th century. Like Nawawi whose students increased by 200 people per year, Mahfuzh is very likely to reach a number that is the same or even more so because of the enormous interest among Southeast Asian students to study at Haramain at the end of the 20th century. The material he taught varied greatly because of his multidisciplinary insight with his special appeal in the field of Hadith.

Mahfuzh al-Tarmasi not only belongs to the Indonesian Santri. Some other important Muslim scholars came from outside Indonesia, and they are Sheikh Sa'dullah al-Maimani, a muftī in Bombay India, Sheikh Umar bin Hamdan, a Hadith expert (muhaddithūn) from Haramain, and the Muqri 'as-Syihab Ahmad bin Abd. God of Syria. This world-wide science transmission network for a variety of reasons has truly raised its reputation among the Javanese Santri. For this community, a 'ālim from Java, like Mahfuzh, whose writings and lectures received international recognition, was not only a highly respected figure but also a role model.

Mahfuzh al-Tarmasi's contribution to the world's scholars can be seen from his students who also became a great Muslim scholar that spread Islamic knowledge all over Indonesia and established and led Pesantrens scattered throughout the archipelago and they are the founders of the largest organization in Indonesia, namely Nahdhatul Ulama (NU).

Through these students, the thoughts of Mahfuzh al-Tarmasi based on the Koran and the Sunnah of the Prophet were inherited and passed on by his students, especially after they finished their studies and returned to their respective countries. Some of his students, some of who lived in Mecca and taught at alMasjid al-Haram, such as Umar Hamdan al-

\footnotetext{
${ }^{51}$ Bruinessen, Kitab Kuning, Pesantren Dan Tarekat: Tradisi-Tradisi Islam Di Indonesia.
} 
Ali Masrur, Wawan Hernawan, Cucu Setiawan, Ayi Rahman
The Contribution of Muhammad Mahfuzh Al-Tarmasi to the Hadith Studies in Indonesia
Mahrasi, Baqir al-Jogjawi, Abdul Muhith alJawi al-Makki and others. But many of them returned home to their beloved homeland, such as KH. M. Hasyim Asy'ari, K.H. Baidlawi Lasem, KH. Maksum Ahmad Lasem and KH. Abdul Wahab Hasbullah. They all brought the thoughts of Mahfuzh al-Tarmasi to Indonesia.

For example, through al-Tarmasi students who settled in Mecca, al-Tarmasi's scholarship, history and path is transmitted to later generations, such as Shaykh Umar Hamdan alMahrasi, the Hadith expert in two holy cities: Mecca and Medina, which after receiving all the Sanad and scientific history of al-Tarmasi, born of the great Muslim scholars, such as Ibrahim ibn Dawud al-Fathani, the leading cleric from Patani, southern Thailand, Muhammad Yasin al-Fadani who was given the title of musnid al-'așr, Sanad expert of the century, also an astronomer, Sayyid Ahmad bin Abdullah bin Sadaqah Dahlan; the son of Sayyid Abdullah bin Shadaqah Dahlan, the leading cleric born in Mecca (d. 1943 AD) in Garut. al-amahAllamah Sayyid Hasan alMasysyath, Sayyid Alawi bin Abbas al-Maliki, Sayyid Amin Quthbi, Sayyid Muhammad Nur Quthbi. Even Yasin al-Fadani called his scientific Sanad connected to al-Tarmasi as the Bulūghul Amāni Lineage. ${ }^{53}$

Among the students of Mahfuzh al-Tarmasi who had a great influence in continuing his thoughts was Hadhratusy Shaykh KH. M. Hasyim Ash'ari. He was the closest student of Mahfuzh al-Tarmasi. KH. Hasyim Ash'ari narrated many traditions from Mahfuzh alTarmasi. As he wrote in his book that "it has been linked to me the history and Sanad of Șahīḥ al-Bukhārī alike 'from beginning to end, from our teacher Sheikh Muhammad Mahfuzh bin Abdullah al-Jawi al-Makki. I read it from 1317 to 1319 in Mecca al-Mukarramah and he gave me the certificate of hahịh al-Bukhārī, as well as the diplomas of other Hadith books." $" 54$

\footnotetext{
${ }^{53}$ Imawan, Al-Tarmasi: Ulama Tanah Suci Dari Tanah Jawi.
}

After getting a diploma and Sanad from Mahfuzh al-Tarmasi, he returned to Indonesia. Then he founded a Pesantren Tebu Ireng in Jombang which coincided on the 26th Rabi'ul Awwal $1317 \mathrm{H}$. The Pesantren is also known as the Madrasah Salafiyah Syafi'iyah. Here, he teaches Islamic sciences in general. Especially he teaches many traditions and the knowledge of traditions which he learned from Mahfuzh al-Tarmasi. In fact, he has been recognized as the first person to teach the Sahih Bukhari Hadith in Indonesia. Therefore, many people from various parts of the archipelago came to study with him. Then they established various Pesantrens and Islamic schools in their respective regions.

In addition to establishing Pesantrens, $\mathrm{KH}$. Hasyim Ash'ari founded an Islamic organization called Nahdlatul Ulama (NU). He was appointed to be its leader and received the title Ra'is Akbar. Therefore, the NU which he founded together with the great Javanese ulama on 16 Rajab 1344 H. / 1926 M. was an institutionalization of the minds of his teachers who had formed him into a great Muslim cleric. The path (Manhaj) that he laid out for NU was the path that had been taken by Muslim scholars before, namely: in matters of faith, following the school of the Ahlus Sunnah wal Jamā'ah; in matters of Fiqh, following the Shafi'i school of thought, and in the field of Sufism, following the schools of al-Syadzili and al-Ghazali. In the Treatise of Ahlussunnah wal Jamā'ah, he explained, the Javanese Muslims of the past were united in thought and school. They are all in the field of Fiqh with Shafi'ite beliefs, in the faith of the ahlus sunnah devout wal jamā'ah Ash'ariyyah, and in the field of Sufism, following Imam al-Ghazali and Abu Hasan al-Syadzili. Besides, KH. Hasyim Asy'ari also developed knowledge from Mahfuzh al-Tarmasi, as a transmitter of the Hadith in East Java with thousands of students and scholars. As Hasyim Ash'ari paid his

\footnotetext{
${ }^{54}$ Imawan, Al-Tarmasi: Ulama Tanah Suci Dari Tanah Jawi.
} 
Ali Masrur, Wawan Hernawan, Cucu Setiawan, Ayi Rahman
Contribution of Muhammad Mahfuzh Al-Tarmasi to the Hadith Studies in Indonesia respects to his teacher, Mahfuzh Tremas could be seen from his sincere encouragement to his students to meet Mahfuzh al-Tarmasi himself in Mecca, while Hasyim himself was also dubbed as a teacher of the Hadith. ${ }^{55}$

Besides KH. Hasyim Asy'ari who was able to carry on the thoughts of Mahfuzh al-Tarmasi in Indonesia, there are also several pesantren whose leaders are the student of al-Tarmasi. These pesantren are Pesantren Wahdah alTullab, in Lasem, which was founded by $\mathrm{KH}$. Khalil, al-Tarmasi's secretary, Pesantren alHidāyah founded by Ma'sum bin Ahmad Lasem (1870-1972), KH. Muhammad Bakir bin Nur (1887-1943) from Yogyakarta, K.H.R. Asnawi Kudus (1861-1959), Mu'ammar bin Kiai Baidawi from Lasem, Central Java, Pesantren Sidogiri by KH. Nawawi in Pasuruan, Pesantren Bahrul Ulum, Pesantren Tambak Beras by KH. Abdul Wahhab Hasbullah, Pesantren Buntet Cirebon, Sheikh 'Abbas, in Buntet, Pesantren Maskumambang, Gresik by KH. Muhammad Fakih bin Abdul Jabbar, Pesantren Bustānu Ushshāqil Qur'ān, Betengan in Demak by KH. Muhammad bin Muhammad Mahfuzh al-Tarmasi who is now led by his son, KH. Muhammad Chariri bin Muhammad, and the Pesantren Tremas, Pacitan founded by KH. Abdul Manan, the grandfather of Sheikh Mahfuzh al-Tarmasi. ${ }^{56}$

A large number of al-Tarmasi students building Pesantren in Java did not deny the role of their students who were in the holy land in building madrasas. It is proven that the contribution and influence of al-Tarmasi's thoughts were able to be continued and maintained by Sheikh Muhammad Yasin alFadani in Mecca. With his sincerity in holding fast to the minds of his teachers, who had Ahlus Sunnah wal Jamā'ah, under the Syafi'i Fiqh and Sunni Sufism, even though at that time, the Arabian Peninsula was no longer under Ottoman rule, but under the kingdom of the
Sa'ud who belonged to Wahhabism. In fact, he had very great attention on the education of women, so he founded Ma'had al-Mu'allimāt in $1377 \mathrm{H}$. and became a friendly madrasa for Muslim women in the Arabian Peninsula. Besides, he also taught at Darul Ulum alDiniyyah, which was founded by Muhsin Ali al-Musawa who was a student of Mahfuzh alTarmasi students, such as al-'Allamah Hasan bin Muhammad al-Musyath, Habibullah bin Ma Yakba al -Sinqiti, Sheikh Umar Hamdan alMahrasi, and Sheikh Abdullah bin Muhammad Ghazi.

The number of Pesantrens and madrassas established by Mahfuzh al-Tarmasi students is proof that Mahfuzh al-Tarmasi's contribution to the Hadith scholars and Pesantren's scholars in Indonesia cannot be separated. Moreover, the Pesantren play an active role in advancing education and printing the character of the nation which breathes Islam Rahmatan Lil 'ālaminn. By looking at the function of the Pesantren in general, the Pesantren function as a center for the study of traditional classical Islamic sciences (Tafaqquh fĩ al-din), including Hadith and Hadith science, as centers of reproduction of Muslim scholars, as centers for preserving Islamic traditions and culture Ahlus Sunnah wal Jamā'ah as well as the center of Islamic da'wah and development, played a major role in advancing Islamic education, morals, and character of the Indonesian nation. Until now, the Pesantren still stand firmly and become the center of science and civilization for knowledge seekers in the archipelago. ${ }^{57}$

From the discussion above, it can be concluded that the Mahfuzh al-Tarmasi network with Pesantren scholars is very strong and significant so that it takes him to the highest position in the Pesantren tradition. This significance is based on several considerations: his position as a well-known Hadith teacher, which is very different from his contemporary

\footnotetext{
${ }^{55}$ Mas'ud, Dari Haramain Ke Nusantara: Jejak Intelektual Arsitek Pesantren.

${ }^{56}$ Imawan, Al-Tarmasi: Ulama Tanah Suci Dari Tanah Jawi.
} 
Ali Masrur, Wawan Hernawan, Cucu Setiawan, Ayi Rahman
The Contribution of Muhammad Mahfuzh Al-Tarmasi to the Hadith Studies in Indonesia scholars, and the nature of the transmission of the Hadith that is in line with the Pesantren tradition, in the sense as a model of his teacher. Moreover, Mahfuzh al-Tarmasi's personality and quality in teaching and writing, which has been widely recognized, cannot be underestimated. ${ }^{58}$

\section{CONCLUSIONS}

After researchers traced the materials and works of Mahfuzh al-Tarmasi on Hadith, the science of Hadith and history about him, it can be concluded that as a great scholar of the 19th century AD, Mahfuzh al-Tarmasi has contributed greatly to the study of Hadith and the science of Hadith in Indonesia with some evidence. His diligence and seriousness in learning and teaching traditions and the knowledge of traditions throughout his life. He was even appointed by the High Priest of Mecca to be a teacher at the Masjid al-Haram, a very prestigious office at that time and only three scholars from Indonesia were able to achieve such an achievement. He has a very large number of students reaching more than four thousand students from various countries, not only from Indonesia but also from India and other Muslim countries. His sincerity in producing works in the field of Hadith and the science of Hadith which are entirely written in Arabic, especially his work entitled Manhaj Dhawī al-Nazar: Sharh Manzūmah 'Ilm al$\bar{A} t h \bar{a} r$, shows that Mahfuzh al-Tarmasi has made a very generous contribution means for the study of Hadith and the science of Hadith in Indonesia. His contribution in forming a network of Hadith scholars and the Pesantren's scholars in Indonesia is also proof that Mahfuzh al-Tarmasi has played a significant role in contributing to the development of Hadith studies and Hadith science in Indonesia. This is proven where the Hadith experts and Hadith science in Indonesia are mostly students of Mahfuzh al-Tarmasi. The influential scholars and leaders of the Pesantren in Indonesia have studied Hadith and Hadith science with Mahfuzh al-Tarmasi. The scholars include KH. M. Hasyim Asy'ari (1817-1947 AD), KH. Abdul Wahhab Hasbullah from Jombang (1888-1971 AD), KH. Bisri Syansuri, KH. Muhammad Bakir bin Nur (1887-1943 AD) from Jogjakarta, KH R. Asnawi Kudus (18611959 AD), Mu'ammar bin Kyai Baidawi from Lasem, KH. Abbas Buntet, and Mbah Ma'shum bin Ahmad, from Lasem (1870-1972 AD).

Based on the facts about Mahfuzh alTarmasi, both in learning and teaching, his works in the fields of Hadith and Hadith science, as well as his contribution to the formation of a network of Hadith scholars and Pesantren scholars in Indonesia, it can be said that the study of Hadith and Hadith science in Indonesia in the present and future cannot be separated from the role and contribution of Mahfuzh al-Tarmasi.

\section{REFERENCES}

Al-Tarmasi, Muhammad Mahfuzh. Kifāyatul Mustafìd Li Mā 'Alā Min Al-Asānīd. Edited by Muhammad Yasin bin 'Isa Al-Fadani AlMakki. Mekkah Al-Mukarramah, n.d.

Al-Tarmasi, Muhammad Maḥfüzh. Manhaj Dhawī Al-Nazar: Sharh Manẓūmah 'Ilm AlÄthār. Beirut-Libanon: Dar Al-Kutub Al'Ilmiyah, 2003.

Azra, Azyumardi. Jaringan Ulama Timur Tengah Dan Kepulauan Nusantara Abad XVII Dan XVIII: Melacak Akar-Akar Pembaruan Pemikiran Islam Di Indonesia. 5th ed. Bandung: Mizan, 1999.

Bruinessen, Martin van. Kitab Kuning, Pesantren Dan Tarekat: Tradisi-Tradisi Islam Di Indonesia. Bandung: Mizan, 1999. Deraman, Fauzi, and Faisal Ahmad Shah. Pengajian Hadith Di Nusantara: Indonesia-

\footnotetext{
58 Mas'ud, Dari Haramain Ke Nusantara: Jejak
} Intelektual Arsitek Pesantren. 
Ali Masrur, Wawan Hernawan, Cucu Setiawan, Ayi Rahman
Contribution of Muhammad Mahfuzh Al-Tarmasi to the Hadith Studies in Indonesia
Selatan Thailand-Singapura. Kuala Lumpur: Jabatan Al-Quran dan Al-Hadith, Akademi Pengajian Islam Universiti Malaya, n.d.

Dhofier, Zamakhsyari. Tradisi Pesantren: Studi Tentang Pandangan Hidup Kyai. VI. Jakarta: LP3ES, 1994.

Dimyathi, Muhammad Habib. Mengenal Pondok Tremas Dan Perkembangannya. Pacitan: Perguruan Islam Pondok Tremas, 2001.

Fauzan, Ahmad. "Syekh Mahfudz Al-Tarmasi: Muhaddis Nusantara." Jurnal TAHDIS 9, no. 2 (2019): 119--145.

Hussin, Hayati, Abdul Rahim Ahmad, Muhammad Hafiz Saleh, Nur Zainatul Nadra Zainol, and Rohana Zakaria. "Contributions of Muhammad Mahfuz AlTarmasiy in The Field of Islamic Studies." International Journal of Engineering \& Technology 7, no. 4.9 (October 2, 2018): 194.

https://doi.org/10.14419/ijet.v7i4.9.20672.

Imawan, Dzul Kifli Hadi. Al-Tarmasi: Ulama Tanah Suci Dari Tanah Jawi, 2015.

Mas'ud, Abdurrahman. "Mahfūz Al-Tirmis̄̄ (D. 1338/1919): An Intellectual Biography." Studia Islamika 5, no. 2 (2014): 27-48. https://doi.org/10.15408/sdi.v5i2.752.

Mas'ud, Abdurrahman. Dari Haramain Ke Nusantara: Jejak Intelektual Arsitek Pesantren. Jakarta: Kencana, 2006.

Mastuki, HS, and M. Ishom El-Saha. Intelektualisme Pesantren: Potret Tokoh Dan Cakrawala Pemikiran Di Era Perkembangan Pesantren. 2nd ed. Jakarta: Diva Pustaka, 2004.

Mohamad, Sabri. "Syeikh Mahfuz Al-Tarmasi: Tokoh Ilmu Qira'at Nusantara." In Prosiding Nadwah Ulama Nusantara (Nun) IV, 2011.

Muhajirin, Muhammad. Mahfudz Al-Tarmasi: Ulama HadisNusantara Pertama. Yogyakarta: Idea Press, 2016.

Mukhlies, Fatkhul. "Peranan Syaikh Mahfuzh Al-Tarmasi Dalam Perkembangan Ulum AlHadits: Studi Kitab Manhaj Dzawi AlNazhar." UIN Sunan Ampel, 2010.

Sayono, Joko. "Perkembangan Pesantren Di Jawa Timur (1900-1942)." Jurnal Bahasa Dan Seni 33, no. 1 (2005): 54-69. 